\title{
Making 'Genuine Friendships' Across Racial Lines: 'Cousin Judy' and her Aboriginal 'Mates'
}

\section{RANI KERIN}

In 1958, soon after the birth of her third child, Judy Inglis (née Betheras, 1930-1962) applied to the Board for Anthropological Research (BAR) and the Social Science Research Council of Australia (SSCR) for research grants in order to 'study some aspects of life of part-aboriginal people living in or about Adelaide', South Australia, later refined to 'the status and influence of married women'. In her application to the BAR, Inglis stipulated that her request arose from the 'need to make arrangements for domestic help'. ${ }^{1}$ An independent researcher with no formal university affiliation, Inglis wanted a grant so that she could hire someone to care for her children while she conducted interviews. An academic advisor from the Australian National University's department of anthropology and sociology, John Barnes, cautioned against stressing the practical consequences of winning a grant in her application to the SSRC: 'These august and all-male academic bodies like to feel that they are giving money in order that good research can be carried out, and like to be able to repress the fact that in doing so a few women will be allowed to escape from the kitchen sink'. ${ }^{2}$ Inglis ignored Barnes' advice. Her application - thought to contain a number of 'unusual features' - left the SSRC somewhat bemused. Unable to reach a decision, it asked whether Inglis would consider appointing 'interviewers whose remuneration could be financed by a research grant' rather than use the money to hire a child-minder. ${ }^{3}$ Frustrated, Inglis replied that she had 'no intention of employing interviewers'. The kind of research she proposed could only be done via the establishment of 'personal relationships' which would involve 'many visits' to Aboriginal peoples' homes at all times of the day and night. ${ }^{4}$ The SSRC was not persuaded, but fortunately the BAR could see merit in her project. It agreed to provide a special grant enabling the department of social studies at the University of Adelaide to employ Inglis as a parttime researcher for one year beginning in March $1959 . .^{5}$

I tell this story as a way of illustrating Inglis' unusual position within academia, as well as her unusual approach to research. As a female researcher studying mixed descent urban Aboriginal women, Inglis was definitely in the minority; being a wife and mother made her even more anomalous. Most anthropologists were male, and most research projects centered on groups of Aboriginal people (usually of full descent, often male) in remote Australia whose way of life was said to resemble precontact conditions. ${ }^{6}$ Acknowledging this fact, Inglis described her "ffield" of study [as] a quaint one', meaning unusual, in that 'urban aborigines [were] scattered around the suburbs'. She sometimes felt disadvantaged 'in having to pay a visit' before making an observation (bursting into people's homes' could be 'harrowing', and made Inglis feel that she had a 'colossal cheek'), yet it was precisely the intimate setting of her research - Aboriginal people's kitchens, lounge-rooms and bedrooms - which encouraged the sharing of intimate information and forging of personal relationships on which her project was based. ${ }^{7}$

Reflecting on the ethics of her research in a lecture to first year social studies students in 1960, Inglis observed: 'You feel friendly, and you are friendly, but it's not a disinterested friendliness. You want to be trusted because you are told more if you are trusted, but you know that in one sense the trust will be betrayed because the study 
will end one day.' By then this aspect of the work no longer bothered Inglis for, as she told her students, she had learned that it was possible to 'make genuine friendships, even under artificial conditions and [that] these [had] the odd effect of validating the other, temporary relationship'. ${ }^{8}$ Inglis did not explain what she meant by 'genuine friendship', however the context of her comment, as well as the nature of the relationships she established with some Aboriginal women, suggest that she was referring to friendships that existed outside the researcher/researched relationship. Inglis used the informal term 'mate' to refer to her Aboriginal friends. ${ }^{9}$ She neither explained what she meant by 'mate', nor questioned whether friendships between white women and Aboriginal women were possible; the meaning of the former, and possibility of the latter, were taken for granted.

Historians have been less sure. When Myrna Tonkinson published 'Sisterhood or Aboriginal Servitude? Black Women and White Women on the Australian Frontier' in 1988 there were very few accounts of relationships of any kind between Aboriginal and non-Aboriginal women. Hers represented a first attempt to theorize this relationship using a variety of literary, historical/biographical and anthropological sources. ${ }^{10}$ Tonkinson's starting point was an essay by anthropologist Diane Barwick which documented the development of close personal relationships and easy familiarity between Aboriginal and white women on a mission station in Victoria during the 1860s. A friend and colleague of Inglis's, Barwick shared Inglis's ethical dilemma and also counted Aboriginal people among her friends. ${ }^{11}$ Importantly, Barwick's historical example of cross-racial friendship was the exception which proved Tonkinson's rule that relationships of 'sisterhood' - defined as 'friendship based on equality' - were rare. The absence of friendships between Aboriginal and white women made 'sense in the logic of colonial relations', Tonkinson explained, because:

In all colonial situations there is an assumption by the colonisers that they are inherently superior to the colonised, so inequality between members of the two groups is intrinsic to the system. Since friendship is founded on notions of affinity and equality between individuals, it is not a condition to which colonial settings are conducive. ${ }^{12}$

Tonkinson's argument proved very persuasive. ${ }^{13}$ However, while it did much to dispel the myth of 'sisterhood' (the idea that gender affinity can transcend racial boundaries), as I have argued elsewhere, it also effectively limited the parameters of our historical imagination to the polarities of 'sisterhood' or 'servitude'; equality or oppression. ${ }^{14}$ Within this framework, the possibility of friendship between Aboriginal women and white women was minimised, if not altogether denied.

As Marc Brodie and Barbara Caine observe, the question of whether crossracial friendships between women were possible in colonial (and post-colonial) settings is one that remains open for debate. ${ }^{15}$ While international feminist and other scholars continue to dispute the possibility of cross-racial friendship along similar lines to those advanced by Tonkinson - ie. that western women have tended, in their dealings with non-western women, to infantilize and 'to deny them the possibility of independence or adult status' - recent Australian scholarship has, by contrast, stressed its possibility. ${ }^{16}$ Works by Anna Cole, Liz Reed, Karen Hughes and Julie Evans among others, have enlarged our understanding of the forms cross-racial friendships could take and have underscored the importance of such friendships in the context of 
generating greater cross-cultural understanding. ${ }^{17}$ These works show that individual white women have formed friendships with Aboriginal people (men and women) from colonial times until the present. Rather than an elusive state of equality, such studies show that what was important in the formation of cross-racial friendships was intimacy and reciprocity or, as Reed writes, 'mutual affection, loyalty and generosity, and a sharing of personal histories'. ${ }^{18}$

Vanessa Smith's recent study of friendship and exchange in the Pacific, Intimate Strangers, points to the potential of cross-racial friendship 'to challenge wider complacencies of readerly sophistication, by being both more obvious and more elusive than we are trained to register'. ${ }^{19}$ Touching on the question of cross-racial friendship within the context of research, Smith tentatively concludes that this 'may be the elided question of anthropological fieldwork'. Few anthropological texts, she observes, 'look at cross-cultural friendship outside of, or indeed within, the local informant relationship'. ${ }^{20}$ But there are some such works. Warwick Anderson, for example, has documented the development of 'intense and often intimate relationships' between the Fore people of the eastern highlands of New Guinea and a 'throng of eccentric and adventurous scientists and anthropologists' who visited there in the late 1950s and early 1960s. Shirley Glasse (now Lindenbaum), Inglis's sisterin-law, was one such researcher. She and her husband Robert were engaged to research kuru, a fatal brain disease that was afflicting the Fore people and, in the process, they became 'their people', Anderson writes; 'the village affiliated them, incorporating them into its social life'. ${ }^{21}$ In the Australian context, Peter Sutton has explored the operation of friendship between individual anthropologists and their chief Indigenous collaborators, a pairing he characterizes as 'unusual couples'. ${ }^{22}$ Importantly, Sutton identifies Barwick, Inglis's colleague and friend, as one of a handful of Australian anthropologists who not only learned to see the world through the eyes of their Indigenous informants/friends, but changed as a result. ${ }^{23}$

The one-sided nature of Inglis' archive makes it impossible to determine, with any certainty, whether her friendships with Aboriginal women were, in fact, genuine (let alone 'unusual'). With only her word to go on, and in light of Sharon Marcus's compelling argument that friendship demands a particular mode of analysis, one in which researchers 'account more fully for what texts present on the surface' rather than 'plumb hidden depths', I do not question the genuineness of Inglis's friendships with Aboriginal women. Instead, in this essay, I explore how and why they were formed. ${ }^{24}$ Part one charts the development of Inglis's friendships with two Aboriginal women who I am calling May Rowland and Wendy Boxer, over a two-year period, from 1959-1961. ${ }^{25}$ This time-frame represents Inglis's active period of research and, sadly, the final years of her life. In 1962 Inglis moved to the Australian Capital Territory for work and was killed in a car accident. Whether her friendships with Rowland and Boxer would have continued had she lived is impossible to know, however, some of her last correspondence indicates that she intended to return to Adelaide to visit her Aboriginal 'mates'. ${ }^{26}$ Part two seeks to explain the resolution of Inglis' internal conflict regarding the nature of her friendships with Aboriginal women. As will become apparent, Inglis managed to resolve her ethical dilemma by embracing an advocacy role; having something to offer helped her to justify her intrusion into her subjects' lives. It also deepened her friendships with Aboriginal women, giving her even greater insight into their personal lives, which in turn made her a more effective (and affective) advocate on their behalf. 
The evidence I draw upon for this essay comes mainly from Judy Inglis' fieldnotes of her encounters with May Rowland and Wendy Boxer and their families; although fieldnotes is probably the wrong term, for they were not exactly written in the 'field'. Preferring informal conversation over formal interview, Inglis wrote the notes of her encounters as soon as she could following her return home. These notes, considered too sensitive to place with the rest of Inglis' papers at the Australian Institute of Aboriginal and Torres Strait Islander Studies, have (until now) been held by her family. For 50-years the important story of cross-racial friendship they document has gone untold (unrecognised rather than suppressed) because of the potentially defamatory nature of some of Inglis' observations.

Expecting that she alone would read and make use of her notes, Inglis commented on anything (and everything) she saw and heard that interested her, from the cleanliness of people's homes to their treatment of their children; from what they were wearing to what they were eating; from their attitudes towards alcohol and premarital sex to their views on other Aboriginal people, exemption and the Aborigines Department. While her comments occasionally reflect poorly on her Aboriginal subjects, and sometimes on herself, her observations are written in a very matter-offact manner. When she began visiting May Rowland, for example, Inglis described her house as 'very big and dilapidated. Medium clean. Linos on floors. Dark, gloomy'. ${ }^{27}$ When, a year later, she noted that the house was 'filthy', that Rowland was still 'in bed' and that there were 'kids everywhere', we gain rare insight into the inner workings of an Aboriginal household grown accustomed to the presence of a white visitor. $^{28}$ The adjective 'filthy', although laden with subjective judgment, was not attended by scorn; it was not meant as a criticism, merely a description. When Inglis visited the following week, she noted that 'beds were made or being made' and that 'clean clothes were being put away'. ${ }^{29}$ Later that week she saw 'dirty washing being packed into a suitcase for boys to take to [the laundromat] to be done'. This practice elicited a personal response from Inglis in the form of an aside: 'This is a funny one', she remarked, '[May is] keen to get the washing done, but spends taxis and [money] on it rather than do it by hand'. ${ }^{30}$ Inglis' mild amusement reflected her sense of disbelief at this different domestic practice rather than a sense of superiority; her intellectual curiosity rather than condescension.

Which is not to suggest that Inglis' fieldnotes are devoid of censure. When Rowland told Inglis that her sister-in-law had a 'boyfriend who want[ed] to marry her', Inglis, who had had several encounters with the young woman, noted scornfully that the man '(must be a halfwit). ${ }^{31}$ Inglis's account of lunch at Rowland's house 'curried rabbit and rice (gluey)' - was equally unkind, yet in both cases her criticisms were clearly identified as separate from her factual/objective report. ${ }^{32}$ Contained within brackets, such comments represented her personal views; what she thought, not what she said. They also tell us something about her personality. After several months of weekly visits, Inglis recorded her willingness to make representations to the Aborigines Department on Rowland's behalf: 'I said I'd go and see them (Thinking to myself: nobody understands the relationship of the Department to darkies like me). ${ }^{, 33}$ Later, when Rowland asked to borrow money for a holiday, Inglis 'told her [she was] $£ 12$ overdrawn and otherwise I would have (would have too). ${ }^{34}$ Glimpses of Inglis's personality are also recorded more directly in her fieldnotes. On one of her early visits 
to Rowland's house, Inglis arrived at the prearranged time only to find that Rowland had gone out: 'I said I'd come in and wait. [Rowland's daughter] said [the] house was upside down. [I] said I'd come in on my head. ${ }^{, 35}$ That visit she 'dried some dishes and mopped up [the] stove', and on the following visit was introduced to a visiting relative as 'the new domestic help'. ${ }^{36}$ Funny, friendly, generous and kind, Inglis could also be critical, but that was part of her charm.

Although not entirely reducible to personality, Inglis's friendships with Aboriginal women owed much to the combination of qualities that formed her distinctive character. An academic referee from the University of Melbourne, Professor A. Boyce Gibson, described Inglis as 'capable, clear-headed and energetic', and as someone who had 'a great gift for enjoying herself which [was] ... an encouragement to all in her environment'. ${ }^{37}$ Inglis's Aboriginal 'mates' shared these qualities; they were like her in many respects. The significance of this is underscored by the fact that Inglis did not form friendships with all of her research subjects. She interviewed dozens of Aboriginal women and while most were very forthcoming, some, such as Lara Michaels, 'said nearly nothing'. ${ }^{38}$ Inglis met Michaels at Boxer's house. The topic of conversation that day was exemption. To be treated as a 'fullcitizen' Aboriginal people in South Australia had to apply for an exemption from the Aborigines Act. Becoming exempted meant ceasing to be Aboriginal in the eyes of the law: for some Aboriginal people this was an attractive prospect, for others it meant losing their identity. ${ }^{39}$ Boxer's view, that 'you have to have one [an exemption] to live a decent life independently of the Aborigines Department', contrasted markedly with Inglis' position: 'I said I thought dark people should stand out against exemption as far as possible because the principal was bad.' Whether Michaels' silence was the result of intimidation or indifference, Inglis's explanation - she wrote that Michaels '[wasn't] interested in principles' - was telling. ${ }^{40}$ Although Inglis and Boxers' positions were different, they were both interested in principles and that, along with other shared views and a willingness to articulate them, helped to make their friendship possible.

For all that they had in common personality-wise, Rowland and Boxer came from a very different world than Inglis. A mother of seven, Rowland had worked as a domestic servant prior to her marriage at the age 17. One of her daughters had been murdered and her three children (Rowland's grandchildren) were living with Rowland at the time of Inglis's visits. Several of Rowland's grown children also lived with her. To help make ends meet Rowland, aged in her mid-fifties, took in paying boarders as well. She controlled the family income, giving her husband just enough money for tobacco each week. Her firm views on alcohol - she told Inglis that she '[wouldn't] tolerate drinking in the house' - were constantly undermined by the men in her family, but she persisted in her campaign, emptying liquor down the sink whenever she could. ${ }^{41}$ Boxer, aged in her early-thirties, had six children fathered by three different men. At the time of Inglis' visits she was living in a de-facto relationship with the father of her first born child. She too had worked as a domestic servant prior to her marriage. Believing that men, on the whole, were irresponsible, she likewise managed the family income. Both women had been born on government run reserves for Aboriginal people, and now lived in rented houses controlled by the South Australian Housing Trust. ${ }^{42}$ Aged in her late-twenties, Inglis had a masters degree in philosophy from the University of Melbourne and a graduate diploma in anthropology from Oxford. She and her husband, a university lecturer, were buying the house they lived 
in with their three children. ${ }^{43}$ Socially, politically and economically Inglis was in a different class to Rowland and Boxer. Their life experiences and cultural background were poles apart and yet, barring an initial period of reserve, this seems not to have mattered.

At their first meeting, Rowland 'didn't have much to say' - Inglis noted that she was 'shy, but friendly'. ${ }^{44}$ On subsequent visits, both women made friendly overtures designed to put the other at ease: Inglis offered to drive Rowland to see a house; Rowland made brownies. ${ }^{45}$ Inglis's fifth visit was conducted in Rowland's bedroom. Sick in bed, Rowland confided her misgivings about her husband - 'she doesn't know why she stuck to [him] except for the children' - and told Inglis that when her youngest child was a baby, her husband (who, she disclosed, was not the father of the child) would 'get drunk and lock them out'. ${ }^{46}$ From that point on, Rowland's shyness evaporated. At lunch at Inglis's house the following week, Rowland asked personal questions about Inglis's conditions of employment and home ownership: 'Did the University pay me? Did we own the house?' Apparently satisfied by Inglis's answers, she shared the gruesome details of her daughter's murder. ${ }^{47}$ After six months of regular visits and phone calls, sometimes several in a week, Rowland, who wore 'the uniform' of the Salvation Army and proudly spoke of leading by example, confessed to 'slipping-up at the races' the previous week. ${ }^{48}$ After eight months, Inglis felt comfortable offering unsolicited advice to Rowland about her eldest son's errant ways: 'I urged her not to pay [his fine] because he wouldn't learn sense that way'. ${ }^{49}$ That Christmas Rowland bought presents for Inglis and her husband. ${ }^{50}$

Inglis's relationship with Boxer started just as coolly. When Inglis arrived for her first interview with Boxer she found her heading out the door. In the end they talked for three hours and Inglis immediately formed an impression of her as a 'strong-minded woman'. Boxer told her about her husband - 'a drinker ... [who] behaved like an animal' - and her 'manfriend' who she planned to marry as soon as a divorce could be arranged. At this first meeting, Boxer revealed her preference for white neighbours and explained that she had had to 'put an end to [the] endless visiting' of Aboriginal family and friends because 'her home wasn't her own, nor the contents'. ${ }^{51}$ Although, as it transpired, this was not exactly true as Inglis observed many Aboriginal guests at her home, it was the principle that mattered. Inglis regarded Boxer as a 'unique phenomonen' - 'she has her feet firmly in the dark world and is on completely good terms with [her white] neighbours'. ${ }^{52}$ Whether she found her 'letting down trousers, teeth out, [and] a bit grumpy', or warm and welcoming, Inglis's admiration for Boxer grew with each visit. ${ }^{53}$ After a year and a half of regular visits, Inglis casually referred to Boxer as her 'best mate' in a letter to Diane Barwick. $^{54}$

\section{II}

Friendship can take many forms. Sutton reminds us that modern Western conceptions of friendship (emotionally positive, voluntary relationships) have only 'modest parallels' and 'no precise equivalent in classical Aboriginal thinking'. In Far North Queensland, for example, he found that the meanings of the English term 'friend' varied from 'marriageable type of cousin, to lover or sweetheart ... to fellow initiation novice, to a term for company'. ${ }^{55}$ While this did not preclude the formation of close relationships, Sutton's point that different cultural conceptions of friendship necessarily affect how each party experiences the relationship is worth exploring, for 
it helps to explain why Rowland and Boxer were so open and generous in their volunteering of personal information.

Suburban Adelaide in the late 1950s was a long way removed from classical Aboriginal thinking. Indeed, the extent to which Aboriginal people of mixed descent in South Australia had a 'distinct culture' was one of Inglis's research questions. Although she ended up arguing that her research subjects did not have a 'distinct "mixed-blood culture" - by which she meant "the persistence of traditional [ie. classical] patterns of behaviour modified to contemporary conditions' - Inglis singled out kinship as a possible exception. 'The fact ... that many part-aboriginal people can impart detailed information about hundreds of their kind is evidence of some sort of connection' with 'traditional' practices, she observed. ${ }^{56}$ One of the implications of this was that Inglis herself was, to a certain extent, incorporated as kin. Following one of her early visits with Rowland, Inglis noted that Rowland's niece had called her 'cousin Judy', after which she and several other Aboriginal women, including Rowland, had proceeded to give Inglis 'bits of family history - who'd had babies for who and who'd divorced who'. ${ }^{57}$ Traditionally, one way for Aboriginal people to establish relationships of trust with outsiders was to incorporate them into Aboriginal society through the mechanism of 'fictive or adoptive kinship'. According to Sutton, this included researchers.

For the Aboriginal person genealogical closeness would be their archetype of emotional trust and nearness, their closest approximation to a European's idea of friendship ... Not just any kind of relationship will do. Aboriginal people have generally structured the relationship in only a few of all possible ways. At the point of incorporation the researcher is typically made a son, a daughter or a sibling of the person first claiming them as kin. ${ }^{58}$

Although the name 'cousin Judy' was probably given tongue-in-cheek, it nevertheless helped to position Inglis as Rowland's adoptive daughter. Whether Inglis appreciated the significance of this is unclear, for apart from referring to Aboriginal people in Adelaide (proprietorially) as 'my mob', she did not comment or openly reflect on it. 59 However, in many respects she assumed a kind of daughter-like role, even to point of giving Rowland her own mother's coat ('As May left she said "Have you got a coat?" I gave her mum's grey one'). ${ }^{60}$ Inglis drove Rowland to the shops, to the Aborigines Department and to look at houses; she cooked for her, counseled her and lent her money. ${ }^{61}$ These small gestures helped to win Rowland's trust, which, as a researcher, was Inglis' goal. While they also made the relationship reciprocal, this alone was not enough to ease Inglis' ethical burden, what Barwick referred to in correspondence with Inglis as 'role conflict'. ${ }^{62}$

Barwick discussed the 'emotional and ethical difficulties' she had faced during the course of her research among Aboriginal people of mixed descent in Victoria in the preface to her doctoral thesis. She had, she wrote, been 'anxious not to take advantage of people who had become friends as well as informants', and had also struggled against the tendency to identify 'too closely with their point of view'. Barwick described this condition as a 'weakness that would not occur to the (probably mythical) impartial-anthropologist-with-a-notebook-appendage of whom we learned in fieldwork training seminars'. Although she recognised it as a 'weakness that most anthropologists' likely shared - 'a very human feeling of responsibility' for the subjects of one's study - for Barwick, the 'ulcerous emotional involvement' of long- 
term participant-observation was almost unbearable. She took small comfort in the knowledge that other researchers had 'probably ... walked three times around the block before paying a visit, debating the worth of anthropology and doubting their right to invade the lives of strangers'. ${ }^{63}$ As we have seen, Inglis was such a researcher. Her dilemma - that 'if you get close enough to someone to get complete accuracy, you are a friend and therefore think twice about using the stuff' - was essentially the same as Barwick's. ${ }^{64}$ But, whereas Barwick, at the point of submitting her dissertation in 1963, was still uncomfortable in the knowledge that she had 'received an undeserved welcome from [her] victims', Inglis, as already mentioned, had found a way to ease her 'nagging conscience'. ${ }^{65}$

The Aboriginal women who participated in Inglis' study were not her victims; they were active participants in a research process that they saw as having advantages for themselves. When Inglis began her research she was often asked 'What good do you think you will do?', a question which she read as implying a sense of underprivilege, but which also implied an expectation - or hope - of positive change. ${ }^{66}$ Having 'no idea if [her work] would do any good' - and cognisant of the fact that her 'first aim' as a researcher was 'not to do good, but simply to uncover new facts' - Inglis joined the Aborigines Advancement League of South Australia (AALSA), an established lobby group with a good reputation for effecting change. ${ }^{67}$ Although largely dominated by white people, the AALSA had several Aboriginal members and was responsible for maintaining a hostel for Aboriginal girls at Millswood, a suburb in Adelaide. ${ }^{68}$ Millswood was a frequent topic of conversation at Rowland and Boxers' houses. Both women thought there was a 'great need ... for [a] boys hostel'; 'a Millswood for boys' and another hostel for young men 'in town looking for work'. Boxer was adamant that the League's emphasis on girls was wrong since they were 'all going to marry and settle down'. ${ }^{69}$ Soon after Inglis joined the AALSA, Boxer joined too. ${ }^{70}$ While her interest in changing Millswood into a hostel for boys quickly faded in the face of a new project - establishing an all-black football club - Boxer's 'wild enthusiasm' for building up 'the self-confidence, self-respect and self-awareness of the dark population' through such initiatives only reinforced Inglis's admiration of her and perception of her as a leader among her people. ${ }^{71}$

Inglis's involvement in the AALSA, and later the Federal Council for Aboriginal Advancement (FCAA), gave her something to offer the subjects of her study beyond pure research and, in the case of Boxer, became something they could share. Half-jokingly, Inglis advised Barwick: 'Don't let anyone tell you that the first principal of social anthropology is not to meddle in what you are studying. It's a most valuable technique!' Barwick, although she later became involved in Aboriginal politics, thought it was 'a mistake to be mixed up in the initial stage of [one's] work with any do-gooder outfit', and Inglis understood her concern. With a mixture of trepidation and pride, she remarked: 'I'm so unpopular in the Abo[rigine]s Dep[artmen]t now, because I mix among their clientele, that I'm not likely to see any more confidential material'. This, however, was a risk that Inglis was prepared to take. Defending her activism on 'humanitarian' grounds, she explained: 'The Dep[artment]t and the policy in [South Australia] are so deplorable that it's hard to shut up' ${ }^{72}$

Apart from her work with the AALSA and the FCAA, Inglis' activism found expression in numerous short articles and opinion pieces published in popular journals such as Nation and the Current Affairs Bulletin, and in public lectures to organisations 
such as the Union of Australian Women. Using her research to inform her activism, Inglis blurred the line between anthropologist and activist in ways that made other anthropologists uncomfortable. J.B. Cleland, former chair of the BAR, saw fit to remind Inglis that, having been granted privileged 'access to much private information', she would do well to 'submit to the Chief Protector [of Aborigines] anything [she] had written before [she] published it' ${ }^{73}$ Other colleagues found her repeated requests for 'practical suggestions' to help Aboriginal people 'discomfiting'. A colleague at the ANU mocked: surely 'one of the joys of anthropology is that one is relieved of the obligation to do this sort of thing'? ${ }^{74}$

Inglis's willingness to blur the line between anthropology and activism was the result of two things: her belief that social researchers needed to immerse themselves in their subject (she told her students that they needed to be 'up [to their] ears in [their] subject') and her friendships with Aboriginal people. ${ }^{75}$ These things were linked. Once she became interested in Aboriginal people, once she began hearing their stories and became entangled in their lives, once she became aware of the full extent of discrimination they suffered, Inglis' moral path was clear: her research led to friendships with Aboriginal people which led to her involvement in the Aboriginal cause. Although this trajectory was not, of course, inevitable, from Inglis' perspective it probably seemed that way.

Mark Peel has observed that in "various forms of activism, friendship was both the outcome and the generator of solidarities across racial, national, religious and class divisions'. Activism, Peel says, 'built upon friendships and it built friendships'. He cites numerous instances of cross-racial friendships emerging and being strengthened during the 1950s and 1960s in the context of civil rights campaigns in the United States. ${ }^{76}$ By contrast, Peel notes that in Australia it was the case that such collaborative relationships were increasingly unfriendly during this period, with nonAboriginal activists being forced to hand over power to Aboriginal campaigners. ${ }^{77}$ Inglis, had she lived, may have faced this too, but it seems unlikely, for she was very firmly of the opinion that non-Aboriginal activists should not 'take [themselves] too seriously as policy inventors because, in the end, dark people will make their own decisions about how they will live'. Inglis knew, from personal experience, that Aboriginal people 'would resist having ideas shoved down their throats by us or anyone'. ${ }^{78}$

Establishing a different connection between cross-racial friendship and activism, Sutton highlights the potential impact of anthropologists' published research to educate and inform a wider audience. Having been 'grown up' by their Aboriginal informants/friends, he explains that the work of anthropologists 'arguably underpinned many milestones in the overcoming of ignorance and prejudice'. ${ }^{79}$ The main piece of research to emerge from Inglis's study was 'Aborigines in Adelaide' published in Journal of the Polynesian Society in 1961. Richly illustrated with examples from her interviews with 30 Aboriginal women householders, it offered a comprehensive account of the main characteristics and way of life of Adelaide's Aboriginal population. Although not overtly political, Inglis's commitment to 'accurately describing' the situation as she found it meant that her essay was inherently political. It dealt particularly with assimilation, offering detailed and considered commentary on the difficulties Aboriginal people faced in trying to live as non-Aborigines. ${ }^{80}$ Several other scholarly articles, including one based on the genealogical information provided by her Aboriginal friends - 'Dispersal of 
Aboriginal Families in South Australia, 1860-1960' - were published posthumously. ${ }^{81}$ Going through her papers after her death, Barwick came across numerous unfinished articles that she thought should be published; one, in particular, she felt could appear in 'several places - it [being] one the least opinionated articles on a complex problem' she had seen for a long time. ${ }^{82}$

\section{Conclusion}

Judy Inglis's interest in Aboriginal people of mixed descent stemmed from their difference, and similarity, to herself: she wanted to understand them and their world, which for her meant becoming part of their world. As a consequence of historical and ongoing discrimination, the Aboriginal people she worked with were profoundly disadvantaged. However, rather than a hindrance to the formation of personal relationships, this lack of equality helped to strengthen the bond between Inglis and her Aboriginal informants. As researcher, advocate and friend, Inglis was intimately acquainted with the inner workings of numerous Aboriginal households. Her relationships with May Rowland and Wendy Boxer were especially close. Their willingness to share their personal, private stories with her was a tribute to both parties; a reflection of Inglis's personality and Rowland's and Boxer's generosity of spirit. Through these relationships Inglis gained privileged insight into the daily lives, routines, and functionality of Aboriginal families during the era of assimilation, and consequently developed a deeper, more nuanced understanding of the problems facing them than most other researchers. That she used this knowledge to press for changes in laws and attitudes highlights the importance of the relationships - the 'genuine friendships' - thus formed. While a direct correlation can be seen between the degree of intimacy achieved and level of anthropological insight obtained, the forging of genuine friendships added an extra layer of complexity involving mutual obligations and responsibilities that is testament to the value of meaningful cross-cultural exchange. If Sutton is correct, and this 'is the kind of reconciliation that matters most', then we, as a society, have something to learn from 'cousin Judy' and her Aboriginal 'mates'. 83

${ }^{1}$ Judy Inglis to secretary, BAR, 22 September 1958 and 22 October 1958, Judy Inglis Papers, Private Collection (PC) held by Kate Inglis.

2 John Barnes to Inglis, 30 September 1958, PC.

${ }^{3}$ H.W. Arndt, honorary secretary SSRC, to Inglis, 27 October 1958, PC.

${ }^{4}$ Inglis to Arndt, 10 February 1959, PC.

${ }^{5}$ V.A. Edgeloe, registrar University of Adelaide, to Inglis, 18 March 1959, Judy

Inglis Papers (JIP), Australian Institute of Aboriginal and Torres Strait Islander

Studies, MS 2907, Item 17.

${ }^{6}$ See Marie de Lepervanche, 'Women, Men and Anthropology', in Julie Marcus, ed., First in their Field: Women and Anthropology in Australia, Melbourne, 1993, pp.610; Geoff Gray, A Cautious Silence: The Politics of Australian Anthropology, Canberra, 2007; Gillian Cowlishaw, 'Aborigines and Anthropologists', Australia Aboriginal Studies, 1 (1986), pp.5-8; Geoff Gray, "[The Sydney School] seem[s] to View Aborigines as Forever Unchanging': Southeastern Australia and Australian Anthropology', Aboriginal History, 24 (2000), pp.175, 191-2. 
${ }^{7}$ Inglis to Ruth Fink, 4 February [1960] and 16 February [1960], JIP, Item 17; Inglis, 'Lecture II', lecture to social studies students, March/April 1960, JIP, Item 18.

${ }^{8}$ Inglis, 'Lecture II'.

${ }^{9}$ See Inglis to Diane Barwick, 6 June [1961] and 14 February [1962], JIP, Item 14.

See also Inglis, fieldnotes of conversation with Wendy Boxer (Fieldnotes: Boxer), 14 September 1959, PC.

${ }^{10}$ Myrna Tonkinson, 'Sisterhood or Aboriginal Servitude? Black Women and White Women on the Australian Frontier', Aboriginal History, 12, 1 (1988), p.27.

${ }^{11}$ See correspondence to and from Diane Barwick in JIP, Item 17.

${ }^{12}$ Tonkinson, pp.34-35.

${ }^{13}$ See Jackie Huggins and Thom Blake, 'Protection or Persecution? Gender Relations in the Era of Racial Segregation', in Kay Saunders and Raymond Evans, eds, Gender Relations in Australia: Domination and Negotiation, Sydney, 1992, pp.53-5; Mary Ann Jebb and Anna Haebich, 'Across the Great Divide: Gender Relations on Australian Frontiers,' in Gender Relations, pp.34-5.

${ }^{14}$ Sitarani Kerin, An Attitude of Respect: Anna Vroland and Aboriginal Rights, 1947 1957, Clayton, 1999, pp.36-8.

${ }^{15}$ Marc Brodie and Barbara Caine, 'Class, Sex and Friendship: The Long Nineteenth Century', in Barbara Caine, ed., Friendship: A History, London, 2009, p.262.

16 ibid.

${ }^{17}$ Anna Cole, Fiona Paisley and Victoria Haskins eds, preface to Uncommon Ground: White Women in Aboriginal History, Canberra, 2005, p.xxix; Liz Reed, “Mrs Bon's Verandah Full of Aboriginals": Race, Class, Gender and Friendship', History Australia, 2, 2 (2005), pp.39.1-39.15; Karen Hughes, "'Same Bodies, Different Skin": Ruth Heathcock', in Uncommon Ground, pp.83-106; Julie Evans, Patricia Grimshaw and Ann Syandish, 'Caring For Country: Yuwalaraay Women and Attachments to Land on an Australian Colonial Frontier', Journal of Women's History, 14, 4 (2003), pp.15-37.

${ }^{18}$ Reed, p.39.2.

${ }^{19}$ Vanessa Smith, Intimate Strangers: Friendship, Exchange and Pacific Encounters, Cambridge, 2010, p.17.

${ }^{20}$ ibid., p.8

${ }^{21}$ Warwick Anderson, The Collectors of Lost Souls: Turning Kuru Scientists into Whitemen, Baltimore, 2008, pp.164-66.

${ }^{22}$ Peter Sutton, The Politics of Suffering: Indigenous Australians and the End of the Liberal Consensus, Melbourne, 2011, p.189. Such couples were 'unusual' in at least two senses, Sutton explains: first because it 'has been historically unusual for two people to commit themselves in such a demanding way to the creation of knowledge and understanding across what has often been a vast cultural divide'; second, because these relationships were not only unusual in Australia's history, 'they have had few consistent parallels anywhere outside the geographic spread of European colonialism, or in any earlier time than the nineteenth century'.

${ }^{23}$ ibid., pp.186-87.

${ }^{24}$ cit. Smith, p. 12.

${ }^{25}$ At the wish of Judy Inglis' family, I have used pseudonyms to protect the privacy of her informants.

${ }^{26}$ Inglis to Barwick, 14 February [1962]. 
${ }^{27}$ Inglis, fieldnotes of conversation with May Rowland (Fieldnotes: Rowland), 14 May 1959, PC.

${ }^{28}$ Fieldnotes: Rowland, 9 February 1960, PC.

${ }^{29}$ Fieldnotes: Rowland, 15 February 1960, PC.

${ }^{30}$ Fieldnotes: Rowland, 18 February 1960, PC.

${ }^{31}$ Fieldnotes: Rowland, 2 November 1959, PC.

${ }^{32}$ Fieldnotes: Rowland, 17 July 1959, PC.

${ }^{33}$ Fieldnotes: Rowland, 7 July 1959, PC.

${ }^{34}$ Fieldnotes: Rowland, 16 July 1959, PC.

${ }^{35}$ Fieldnotes: Rowland, 12 June 1959, PC.

${ }^{36}$ Fieldnotes: Rowland, 16 June 1959, PC.

${ }^{37}$ A. Boyce Gibson, personal reference, 29 July 1952, PC.

${ }^{38}$ Fieldnotes: Boxer, 31 March 1960 and 7 April 1960, PC.

${ }^{39}$ See Inglis, 'Aborigines in Adelaide', Journal of the Polynesian Society, 70, 2 (1961), p.213.

${ }^{40}$ Fieldnotes: Boxer, 31 March 1960 and 7 April 1960.

${ }^{41}$ Fieldnotes: Rowland, 4 February 1959 to 1 September 1960, PC; Inglis, raw questionnaire data presented in rough table form, PC.

${ }^{42}$ Fieldnotes: Boxer, 16 July 1959 to 12 May 1960, PC; Inglis, raw questionnaire data. See also Inglis to Barwick, 24 March [1961], JIP, Item 14.

${ }^{43}$ Ken Inglis, interviewed by Rani Kerin, 20 May 2005, transcript in author's possession. See also Rani Kerin, ' Mixed up in a Bit of Do-Goodery': Judy Inglis, Activist Anthropology and Aboriginal History', History and Anthropology, 18, 4 (2007), p.429.

${ }^{44}$ Inglis made contact with Rowland and Boxer through a mutual acquaintance. She wrote to them, explained her business and asked if she might visit them. Inglis, "Lecture II"; Fieldnotes: Rowland, 14 February 1959, PC.

${ }^{45}$ Fieldnotes: Rowland, 12 June 1959 and 16 June 1959.

${ }^{46}$ Fieldnotes: Rowland, 19 June 1959, PC.

${ }^{47}$ Fieldnotes: Rowland, 24 June 1959, PC.

${ }^{48}$ Fieldnotes: Rowland, 24 August 1959, PC.

${ }^{49}$ Fieldnotes: Rowland, 1 December 1959, PC.

${ }^{50}$ Fieldnotes: Rowland, 8 January 1960, PC.

${ }^{51}$ Fieldnotes: Boxer, 31 July 1959, PC.

${ }^{52}$ Fieldnotes: Boxer, 24 February 1960, PC.

${ }^{53}$ Fieldnotes: Boxer, 17 December 1959 and 18 February 1960. PC.

${ }^{54}$ Inglis to Barwick, 24 March [1961].

${ }^{55}$ Sutton, pp.191-92.

${ }^{56}$ Inglis, 'Dispersal of Aboriginal Families in South Australia (1860-1960)', in Marie Ray, ed., Aborigines Now: New Perspective in the Study of Aboriginal Communities, Sydney, 1964, p.130.

${ }^{57}$ Fieldnotes: Rowland, 16 June 1959.

${ }^{58}$ Sutton, p. 192.

${ }^{59}$ Inglis to Barwick, 18 February 1961, PC.

${ }^{60}$ Fieldnotes: Rowland, 24 June 1959.

${ }^{61}$ Fieldnotes: Rowland, 12 June 1959, 17 July 1959, 8 January 1960.

${ }^{62}$ See Inglis to Barwick, 24 March [1961]. 
${ }^{63}$ Diane Barwick, 'A Little More Than Kin: Regional Affiliations and Group Identity Among Aboriginal Migrants in Melbourne', $\mathrm{PhD}$ thesis, Australian National University, 1963, pp.xxv-xxvi.

${ }^{64}$ Inglis to Barwick, 24 March [1961].

${ }^{65}$ Barwick, 'A Little More Than Kin', p.xxvi. See also Inglis, 'Review of Burridge, K.O.L (1960) Mambu, a Melanesian Millenium', Journal of the Polynesian Society, 3 (1961), pp.381-84.

${ }^{66}$ Inglis, 'Aborigines in Adelaide', p.205.

${ }^{67}$ Inglis, "Lecture II". See also Minutes of the Aborigines Advancement League of South Australia, 24 October 1960, Papers of the Aborigines Advancement League, SRG 250, Series 3/2, State Library of South Australia.

${ }^{68}$ For more on the AALSA, see S. Kerin, 'Doctor Do-Good? Charles Duguid and Aboriginal Politics, 1930s-1970s', PhD thesis: Australian National University, 2004, pp.228-55; Rani Kerin, Doctor Do-Good: Charles Duguid and Aboriginal Advancement, 1930s-1970s, Melbourne, 2011, pp.148-60; Rani Kerin, 'Charles Duguid and Aboriginal assimilation in Adelaide, 1950-1960: The nebulous 'assimilation' goal', History Australia, 2, 3 (2005), pp.85.1-85.17.

${ }^{69}$ Fieldnotes: Rowland, 14 May 1959; Boxer, 18 February 1960.

${ }^{70}$ Fieldnotes: Boxer, 12 May 1960.

${ }^{71}$ Fieldnotes: Boxer, 16 June 1960, PC; Inglis, 'Aborigines in Adelaide', p.216.

${ }^{72}$ See Inglis to Barwick, 18 February 1961.

${ }^{73}$ Inglis, notes on a conversation with J.B. Cleland, 16 February 1961 (see Inglis to WEH Stanner, 14 March 1961), JIP, Item 10.

${ }^{74}$ Jeremy Beckett to Inglis, 31 July 1961, JIP, Item 9.

${ }^{75}$ Inglis, "Lecture II".

${ }^{76}$ Mark Peel with Liz Reed and James Walter, 'The Importance of Friends: The Most Recent Past', in Friendship: A History, pp.328-32.

${ }^{77}$ A connection between activism and cross-racial friendship is implied in Liz Reed's study of Anne Bon, and evidenced more strongly in Leela Gandhi's study of latenineteenth century British radicals who befriended visiting Indians. See Reed, "Mrs Bon's Verandah"'; Leela Gandhi, Affective Communities: Anticolonial Thought, Finde-Siecle radicalism and the Politics of Friendship, Durham, 2006.

${ }^{78}$ Inglis, typescript conference paper 'Detribalised Reserves', FCAA Conference, Adelaide [Easter] 1962, JIP, Item 9.

${ }^{79}$ Sutton, pp.189-90.

${ }^{80}$ Inglis, 'Aborigines in Adelaide'.

${ }^{81}$ Judy Inglis, 'The Assimilation of Poisoned Flour', Nation, 19 May 1962, p.7; Judy Inglis, 'One Hundred Years at Point McLeay, South Australia', Mankind, 5, 12 (1962), pp.503-7; Judy Inglis, 'Aborigines in Adelaide', in W.E.H. Stanner and H. Shiels, eds, Australian Aboriginal Studies, Melbourne, 1963, pp.115-32; Inglis, 'Dispersal of Aboriginal Families in South Australia (1860-1960)'.

${ }^{82}$ Barwick to Shirley Andrews, 26 August 1962, JIP, Item 9.

${ }^{83}$ Sutton, p.193. 